\title{
Virulence properties of motile aeromonads isolated from farmed frogs Rana tigerina and $R$. rugulosa
}

\author{
M. D. Pearson ${ }^{1, *}$, I. Hirono ${ }^{2}$, T. Aoki ${ }^{2}$, Rolando Miranda ${ }^{3}$, V. Inglis ${ }^{1}$ \\ ${ }^{1}$ Institute of Aquaculture, University of Stirling, Stirling FK9 4LA, Scotland, UK \\ ${ }^{2}$ Laboratory of Genetics and Biochemistry, Department of Aquatic Biosciences, Tokyo University of Fisheries, Konan 4-5-7, \\ Minato-ku, Tokyo 108, Japan \\ ${ }^{3}$ Bureau of Fisheries and Aquatic Resources, 860 Quezon Ave., Quezon City, Metro Manila 3008, The Philippines
}

\begin{abstract}
Virulence factors were compared in Aeromonas species isolated from clinically normal and septicaemic farmed frogs from Thailand. Haemolysin activities against frog erythrocytes were significantly different within the collection of aeromonads. Groups of high haemolytic activity (unspeciated Aeromonas, Au), moderate haemolytic activity (A. hydrophila), and low haemolytic activity ( $A$. veronii biovar sobria, $A$. veronii biovar veronii, $A$. caviae, $A$. schubertii) were noted. DNA colony hybridisation studies revealed that $\mathrm{Au}$ isolates possessed a haemolysin gene (ASH1) which was not present in any of the other Thai aeromonads or type strains tested. Elastinolytic activity was demonstrated in $90 \%$ of the Au isolates, $60 \%$ of the A. hydrophila isolates and in none of the other motile aeromonads. The cytotoxic activity of the Aeromonas isolates varied according to the source of cells used in the assays. Cells from rainbow trout were extremely sensitive to Au toxins but less so to toxins produced by other species. In contrast mammalian cells showed very little sensitivity to Au toxins but were more sensitive to toxins produced by A. hydrophila. Selection of suitable assay substrates is therefore important.
\end{abstract}

KEY WORDS: Aeromonas - Haemolysin $\cdot$ Cytotoxin - Elastase

\section{INTRODUCTION}

Motile Aeromonas species have been recognised as pathogens of poikilothermic animals for over a hundred years (Carnahan \& Altwegg 1996). Recently members of the genus have been recognised as human pathogens, giving rise to both intestinal and extraintestinal infections (Janda \& Duffey 1988).

Aeromonas spp. produce a range of extracellular toxins and enzymes and studies have attempted to correlate the production of potential virulence determinants with the pathogenicity and source of Aeromonas isolates (Hsu et al. 1981, Santos et al. 1988, Kirov et al. 1994, Majeed \& MacRae 1994, Pin et al. 1994, Esteve et al. 1995, Vadivelu et al. 1995). Production of protease

\footnotetext{
•E-mail: m.d.pearson@stir.ac.uk
}

and haemolysin in particular have been implicated as key extracellular activities associated with pathogenicity of infections in both animals and humans (Cahill 1990, Janda 1991, Janda et al. 1994). Aeromonas culture supernatants are however multifunctional; therefore understanding the role of individual extracellular toxins in the pathogenesis of septicaemic disease is difficult. Aerolysin, an extracellular, heat-labile haemolysin is a prime example of this problem. In addition to being haemolytic it is also cytolytic and enterotoxigenic (Asao et al. 1984, Janda 1991).

The aerolysin gene from Aeromonas hydrophila has been cloned and sequenced by Howard et al. (1987). Further studies indicated that aerolysin-like haemolysins are widely distributed in aeromonads (Hirono \& Aoki 1992, 1993, Hirono et al. 1992). It has been demonstrated however that various haemolysin genes with different structures are also present in aeromon- 
ads. Two haemolysin genes designated $\mathrm{AHH}-1$ and AHH-2, which showed low homology values with each other and with the aerolysin gene sequence, were cloned from a single A. hydrophila isolate (Aoki \& Hirono 1991). In addition a third gene cloned from an isolate of $A$. salmonicida and designated ASH1 showed no homology with any Aeromonas haemolysin gene sequences published in the DNA data banks. The exact role of haemolysins in the pathogenesis of Aeromonas septicaemias has yet to be fully elucidated.

Outbreaks of motile aeromonad septicaemia can reach epidemic proportions in farmed aquatic animals, with high rates of mortality (Joseph \& Carnahan 1994). In a survey of frogs farmed in Thailand, aeromonads conforming to the phenospecies Aeromonas hydrophila, A. sobria biovar sobria, A. sobria biovar veronii, A. caviae and A. schubertii were isolated from the skin and intestine of clinically normal and septicaemic frogs. The aeromonads consistently isolated from the internal organs of septicaemic, adult frogs however did not conform to any previously described Aeromonas phenospecies or genospecies and were designated Aeromonas unspeciated (Au) (Pearson et al. 1997).

This study was undertaken to examine the haemolytic, cytotoxic and proteolytic properties of the Aeromonas extracellular products and determine whether these could be linked to the origin of bacterial isolates or phenospecies identified.

\section{MATERIALS AND METHODS}

Bacterial isolates and culture conditions. The motile Aeromonas isolates used in this study are listed in Table 1. The bacteria were isolated on tryptone soya agar (TSA, Oxoid) and Aeromonas selective media (Oxoid). Isolates were phenotyped on the basis of their biochemical reactions in the API 20 E system (BioMerieux, France) and following the identification system (Aerokey II) described by Carnahan et al. (1991). During the course of the study isolates were maintained for short periods at room temperature on TSA slants and for longer term at $-70^{\circ} \mathrm{C}$ in cryo-preservative in commercially prepared glass beads (Protoct, UK). Isolates were subsequently recovered in tryptone soya broth (TSB, Oxoid) and subcultured on TSA. All bacterial cultures were incubated at $30^{\circ} \mathrm{C}$.

Preparation of extracellular products. Five $\mathrm{ml}$ of TSB were inoculated with 1 bacterial colony and incubated for $24 \mathrm{~h}$ at $30^{\circ} \mathrm{C}$. The bacterial suspension was then centrifuged at $3000 \times g$ for $10 \mathrm{~min}$ at $4^{\circ} \mathrm{C}$. The supernatant was removed and filtered through a $0.45 \mu \mathrm{m}$ filter. The filtered supernatant was stored at $4^{\circ} \mathrm{C}$ for no more than $24 \mathrm{~h}$.
Table 1. Aeromonas isolates. NCIMB = National Collection of Industrial and Marine Bacteria. CECT = Coleccion Espanola de Cultivas Tipo

\begin{tabular}{|c|c|c|}
\hline Phenospecies & of strains & Sources \\
\hline $\mathrm{Au}$ & 11 & $\begin{array}{l}\text { Frog liver (7), frog muscle } \\
\text { (2), frog heart (1), frog } \\
\text { spleen (1) }\end{array}$ \\
\hline A. hydrophila & 13 & $\begin{array}{l}\text { Frog intestine (2), tadpole } \\
\text { liver (2), tadpole kidney } \\
\text { (1), tadpole intestine (2), } \\
\text { tadpole skin (4), pond } \\
\text { water (1), NCIMB } 9240\end{array}$ \\
\hline A. veroniu bv sobria & 12 & $\begin{array}{l}\text { Frog intestine ( } 3 \text { ), frog skin } \\
\text { (4), tadpole kidney (1), } \\
\text { tadpole intestine (1), tad- } \\
\text { pole skin (1), pond water } \\
\text { (1), NCIMB } 37\end{array}$ \\
\hline A. veronii bv veronii & 4 & $\begin{array}{l}\text { Frog intestine (2), tadpole } \\
\text { skin (1), CECT } 4257\end{array}$ \\
\hline A. caviae & 6 & $\begin{array}{l}\text { Frog intestine (2), frog } \\
\text { skin (3), CECT } 838\end{array}$ \\
\hline A. schubertii & 2 & Frog skin (1), CECT 4240 \\
\hline A. salmonicida & 1 & CECT 894 \\
\hline A. sobria & 1 & CECT 837 \\
\hline A. media & 1 & CECT 4232 \\
\hline A. eucrenophila & 1 & CECT 4224 \\
\hline A. jandaei & 1 & CECT 4228 \\
\hline A. trota & 1 & CECT 4255 \\
\hline A. allosaccharophila & 1 & CECT 4199 \\
\hline A. encheleia & 1 & CECT 4342 \\
\hline
\end{tabular}

Preparation of blood cell suspensions. Chinese bullfrogs Rana rugulosa were anaesthetised with $4 \mathrm{ml}$ of $2.5 \%$ benzocaine (dissolved in ethanol) per $10 \mathrm{l}$ of water. Blood was withdrawn by cardiac puncture into a heparin-coated syringe, placed in a solution of $9.5 \mathrm{ml}$ sterile physiological saline with $0.5 \mathrm{ml}$ heparin and spun at $1000 \times g$ for $15 \mathrm{~min}$. The supernatant was discarded and the blood cells were resuspended 1:400 with sterile physiological saline. Blood was only withdrawn from frogs which were considered clinically normal, i.e. those which exhibited skin lustre, bright eyes, an energetic feeding response and actively attempted to evade capture.

Haemolysin assay. Volumes $(100 \mu l)$ of prepared blood cell suspension were added to doubling dilutions of $100 \mu \mathrm{l}$ of ECPs in $100 \mu \mathrm{l}$ of sterile saline on a microtitre plate (U-bottomed wells). Each supernatant was tested in duplicate on each plate. $100 \mu \mathrm{l}$ of blood cell suspension was added to $100 \mu \mathrm{l}$ of saline to act as a control. Plates were incubated for $1 \mathrm{~h}$ at $37^{\circ} \mathrm{C}$ and then for $12 \mathrm{~h}$ at $4^{\circ} \mathrm{C}$. Haemolytic titres were expressed as the reciprocal of the highest dilution of crude ECP needed to produce partial haemolysis of erythrocytes. 
Detection of haemolysin genes by colony hybridisation. Ten $\mathrm{Au}$ isolates, a selection of speciated Thai aeromonads and 13 Aeromonas type strains (see Table 2) were screened for homologous sequences to cloned haemolysin genes AHH1, AHH4, ASA 1 and ASH1, following colony hybridisation methods described previously (Hirono \& Aoki 1993). DNA probes were labelled with $\alpha^{32} \mathrm{P}$-dCTP $\left(>3000 \mathrm{Ci} \mathrm{ml} \mathrm{m}^{-1}\right.$, Du Pont-NEN Corp., Boston, MA, USA) using a commercial random-primer labelling kit (TaKaRa Random Primer DNA Labelling Kit, Version 2, TaKaRa Biomedicals, Japan). Colonies of each test bacterium were transferred to a portion of Hybond ${ }^{\mathrm{M}}-\mathrm{N}^{+}$; positively charged nylon membrane (Version 2.0, Amersham Life Science, Amersham International plc, UK). Transformed E. coli colonies containing known haemolysin gene inserts provided positive controls. The membranes were incubated with the labelled haemolysin DNA for $12 \mathrm{~h}$ at $42^{\circ} \mathrm{C}$. Hybridisation proceeded under highly stringent conditions. After hybridisation, membranes were washed at $60^{\circ} \mathrm{C}$ for 10 to $15 \mathrm{~min}$ each in: $2 \times \mathrm{SSC}(20 \times$ stock solution of $3 \mathrm{M} \mathrm{NaCl}, 0.3 \mathrm{M} \mathrm{Na}_{3}$ citrate, $\mathrm{pH} 7.0$, diluted in distilled water); $0.1 \%$ sodium dodecyl sulphate (SDS); $0.5 \times \mathrm{SSC}$ - $0.1 \%$ SDS $_{i}$ then in $0.1 \times$ SSC - $1 \%$ SDS. The washed membranes were exposed to Fuji X-ray film (Fuji Photo Film Co., Kanagawa, Japan) at $-80^{\circ} \mathrm{C}$ for $24 \mathrm{~h}$.

Elastase assay. The elastinolytic activity of the Aeromonas isolates was evaluated using a quantitative plate assay technique described by Hsu et al. (1981). Ten $\mathrm{ml}$ of TSB were inoculated with a single colony of test bacteria from an overnight culture on TSA and incubated at $30^{\circ} \mathrm{C}$ for $24 \mathrm{~h}$. Elastin modified agar plates were spot inoculated using a multipoint inoculator (Denley) to give $1 \mu$ l of each bacterial suspension containing approximately $10^{6} \mathrm{cfu} \mathrm{m}^{-1}$. Each bacterial suspension was tested in duplicate with 4 inocula plate ${ }^{-1}$

The inoculated plates were incubated at $30^{\circ} \mathrm{C}$ for $72 \mathrm{~h}$, and the size of the zones of clearing was measured. A zone ratio was obtained by dividing the diameter of the zone of reaction by the diameter of its colonial growth. The elastinolytic activity was defined from the zone ratio values as negative, intermediate or positive according to a ratio of 0 , between 0 and 3 , and higher than 3 respectively.

Cytotoxicity assays. Cytotoxicity assays were carried out following a modification of the method described by Wilcox et al. (1994) on Vero (African green monkey kidney), RTG-2 (rainbow trout gonad), SSN-1 (snakehead) and HCT (catfish) cell lines.

Doubling dilutions of $100 \mu \mathrm{l}$ of ECPs in $100 \mu \mathrm{l}$ of phosphate buffered saline (PBS) were prepared in flatbottomed 96 -well microtitre plates; each supernatant was tested in duplicate on each plate. Cell suspensions $(100 \mu \mathrm{l})$ containing approximately $1 \times 10^{6}$ cells $\mathrm{ml}^{-1}$ were added to each well. As a negative control, cell suspensions were added to doubling dilutions of the TSB.

Cytotoxicity was assessed by visual observation at $\times 40$ with an Olympus IMT-2 phase-contrast inverted microscope. Cytotoxicity was defined as $\geq 50 \%$ cells lysed within a $24 \mathrm{~h}$ period for the Vero cells and within $3 \mathrm{~d}$ for the fish cell lines. Toxicity titres were expressed as the reciprocal of the highest dilution of crude ECP able to produce a cytotoxic response. Cytotoxin positivity was defined as a reciprocal titre of $\geq 4$.

Data analysis. Haemolytic, elastinolytic and cytotoxic data were analysed in the statistics package SigmaStat ${ }^{(3)}$ (Jandel Scientific) using ANOVA and Dunn's all pairwise multiple comparison procedures.

\section{RESULTS}

\section{Haemolytic, elastinolytic and cytotoxic properties}

The haemolytic, elastinolytic and cytotoxic activities of the individual Aeromonas isolates are depicted graphically in Figs. 1 to 6 . Haemolysin production determined against frog erythrocytes allowed division of the isolates into 3 groups of high, moderate and low activity (Fig. 1). The high activity group were all Au isolates from internal locations in adult frogs. Those with moderate activity were A. hydrophila isolated from external locations in adult frogs and tadpoles and 3 internal isolates from tadpoles. The remaining group of low haemolytic activity were from the same locations as the $A$. hydrophila isolates but were different species, i.e. mainly $A$. veronii biovar sobria with a few isolates of $A$. caviae, $A$. veronii biovar veronii and $A$. schubertii. Analysis of the data using all pairwise multiple comparison procedures (Dunn's method) revealed that the differences in haemolytic titre between the 3 groups were highly significant ( $\mathrm{p} \leq 0.01)$.

Elastinolytic activity was demonstrated in $90 \%$ of the Au isolates examined, $60 \%$ of the Aeromonas hydrophila isolates and in none of the other motile aeromonads (Fig. 2). The range of zone ratios was similar for $\mathrm{Au}$ and A. hydrophila; Au ratios ranged from 0 to 3.6 and $A$. hydrophila ratios from 0 to 3.2. Zone ratios were consistent; 8 of the 9 Au isolates and 2 of the 3 positive A. hydrophila had zone ratios greater than 3 . Analysis of the data using all pairwise multiple comparison procedures (Dunn's method) revealed that there was a significant difference between the zone sizes of the $\mathrm{Au}$ isolates and those of the other Aeromonas species $(p<0.05$ ) but not between Au and the $A$. hydrophila isolates or between the $A$. hydrophila isolates and the other Aeromonas species.

The production of cytotoxins was determined in different mammalian and fish cell lines. The cytotoxic activity of all the aeromonads varied according to the 


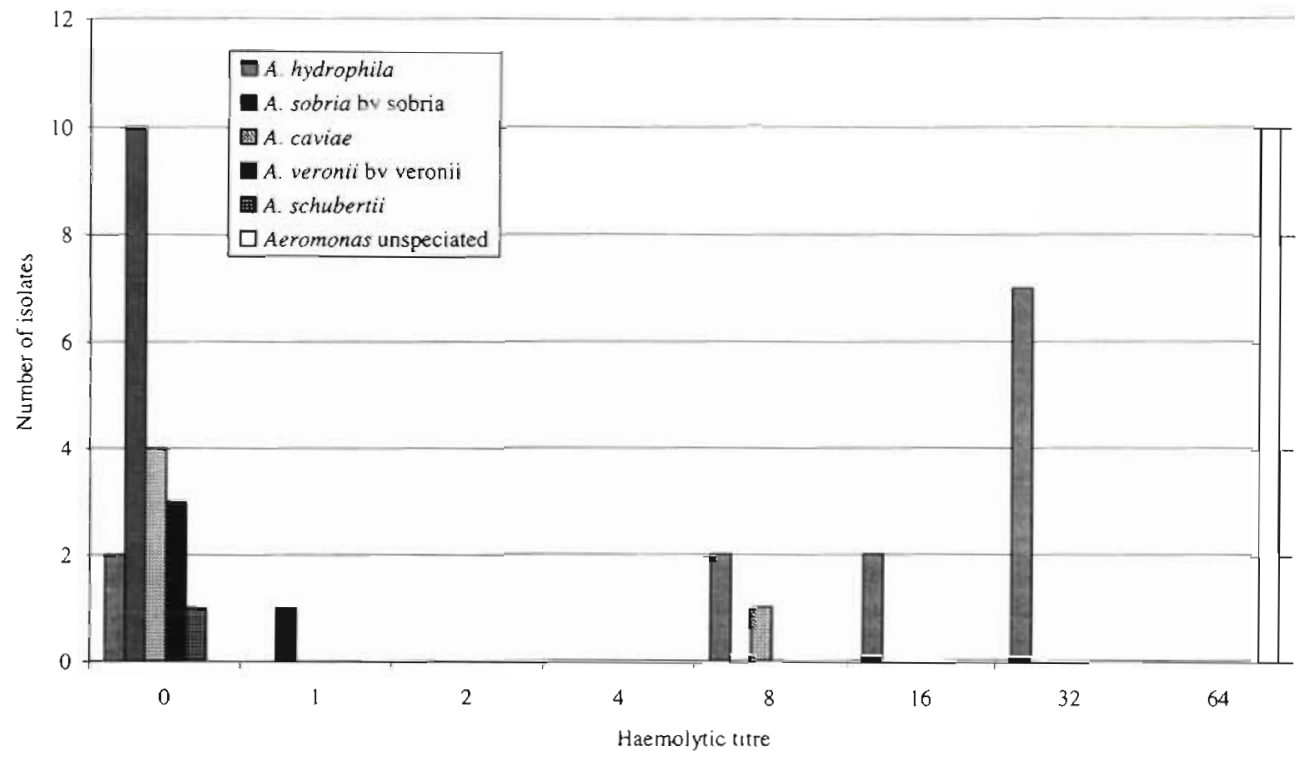

Fig. 1. Haemolytic activity of Aeromonas isolates

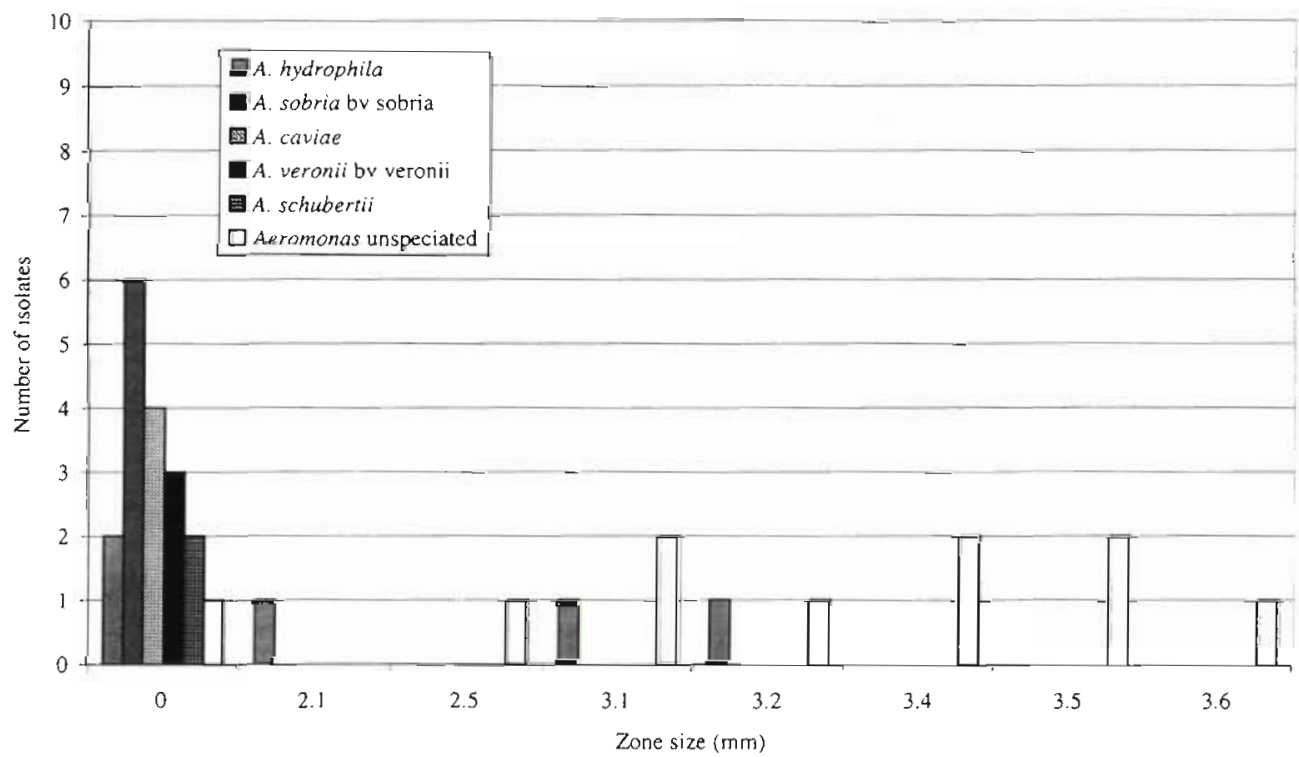

Fig. 2. Elastinolytic activity of Aeromonas isolates

cell line used; however, this variation was most marked in the $\mathrm{Au}$ isolates. All the Au isolates displayed strong cylotoxic activity against rainbow trout cells (RTG-2) (Fig. 3). Titres were consistent with 7 isolates yielding a titre of 256 and the remaining 3 isolates yielding a titre of 128 , a difference of only a single 2 -fold dilution. In comparison a selection of 10 Aeromonas hydrophila from Thailand plus 1 type strain yielded titres ranging from 0 to 64 with little consistency in the results. The remaining group of motile aeromonads consisting of $A$. veronii biovar sobria, $A$. veronii biovar veronii, $A$. caviae and $A$. schubertii displayed much lower cytotoxicity titres ranging from 0 to 16 . This division of the cytotoxic activity into 3 groups of high, moderate and low activity parallels that of the haemolytic titres of Acromonas ECPs against frog blood.

In contrast results from the mammalian cell line (Vero) produced a different profile (Fig. 4). All the Au isolates displayed very little cytotoxic activity against this cell line although the results were again consistent. Six isolates yielded a titre of 0 while the remaining 4 isolates yielded a titre of 2 . Cytotoxin positivity was defined as a reciprocal titre of $\geq 4$ (Wilcox et al. 1994), therefore $100 \%$ of $\mathrm{Au}$ isolates did not possess a cytotoxin active against Vero cells. Several of the Aeromonas hydrophila isolates, however, displayed 


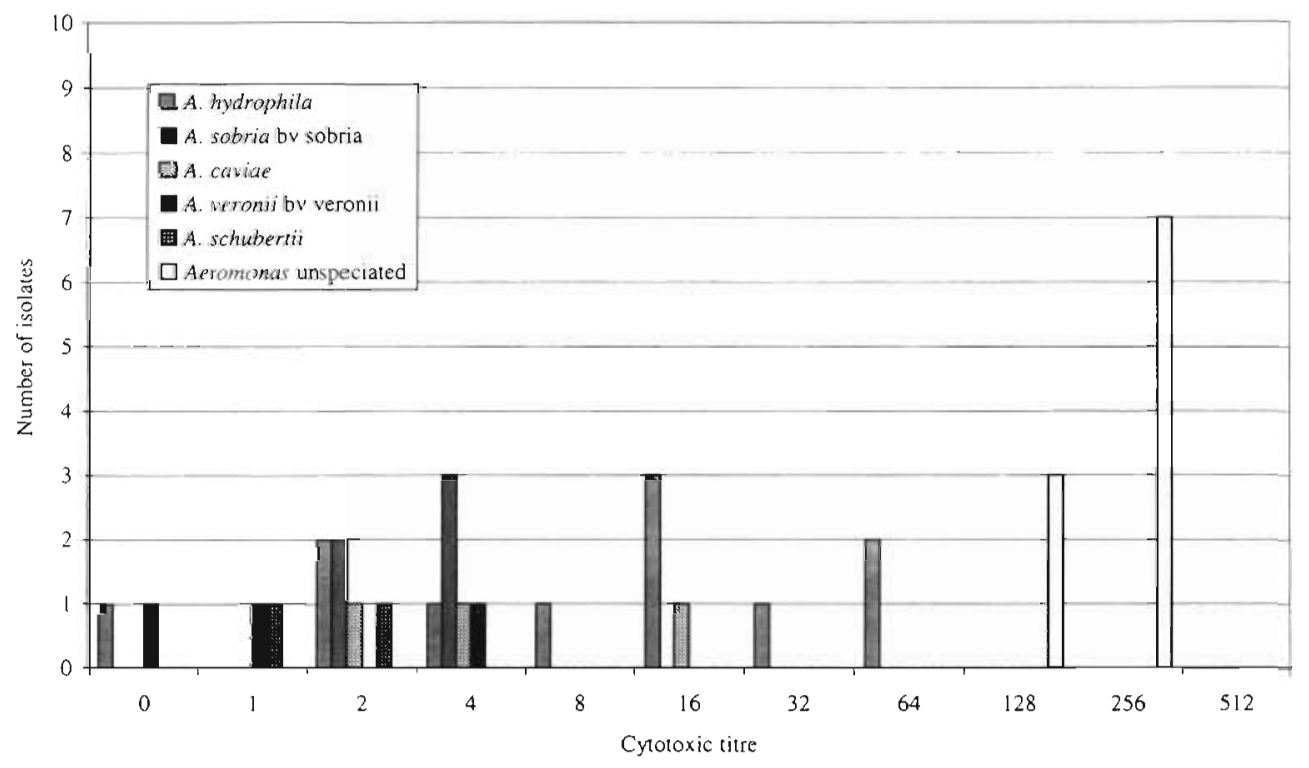

Fig. 3. Cytotoxic activity against RTG-2 cells

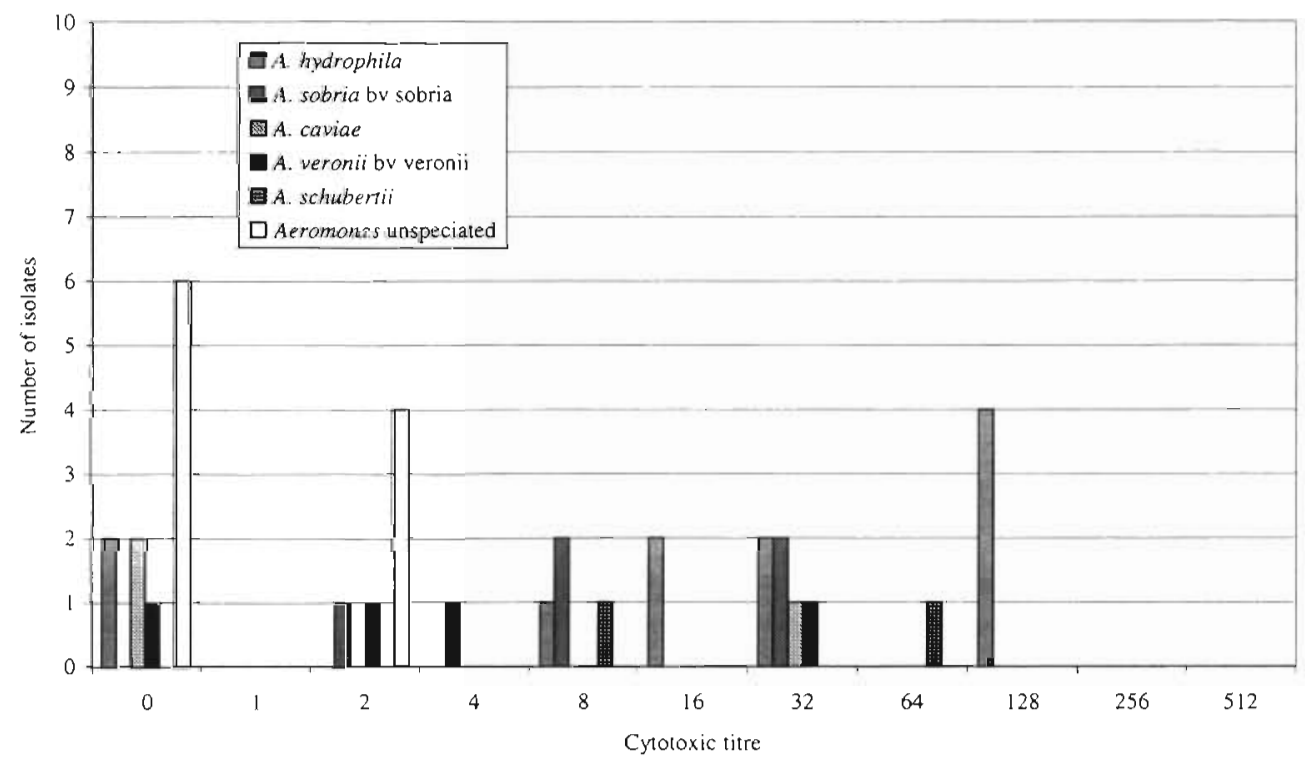

Fig. 4. Cytotoxic activity against Vero cells

strong cytotoxic activity; 4 of the 11 isolates displayed titres of 128 , although titres were again variable ranging from 0 to 128 . Titres for the remaining Aeromonas species were lower from 0 to 64 with 5 isolates yielding titres of less than 4 .

The division of titres into high, moderate and low activity groups were less distinct with the snakehead (SSN-1) (Fig. 5) and catfish (HCT) (Fig. 6) cell lines. Au titres appeared higher than those for Aeromonas hydrophila and the other aeromonads but showed more variation, ranging from 4 to 64 against SSN-1 and 32 to 512 against HCT. The SSN-1 cell line titres ranged from 2 to 32 with $A$. hydrophila titres and from 0 to 16 with the other Aeromonas species ( 7 of which were less than 4). The HCT titres showed even less distinction with $A$. hydrophila and the other motile aeromonads yielding the same range from 0 to 128 .

\section{Haemolysin colony hybridisation}

Results are shown in Table 2. Under highly stringent conditions the AHH1 probe (cloned from Aeromonas hydrophila) hybridised with all the Au strains tested, with 3 out of 4 A. hydrophila isolates from Thailand, and with the type strains of $A$. hydrophila and $A$. sal- 


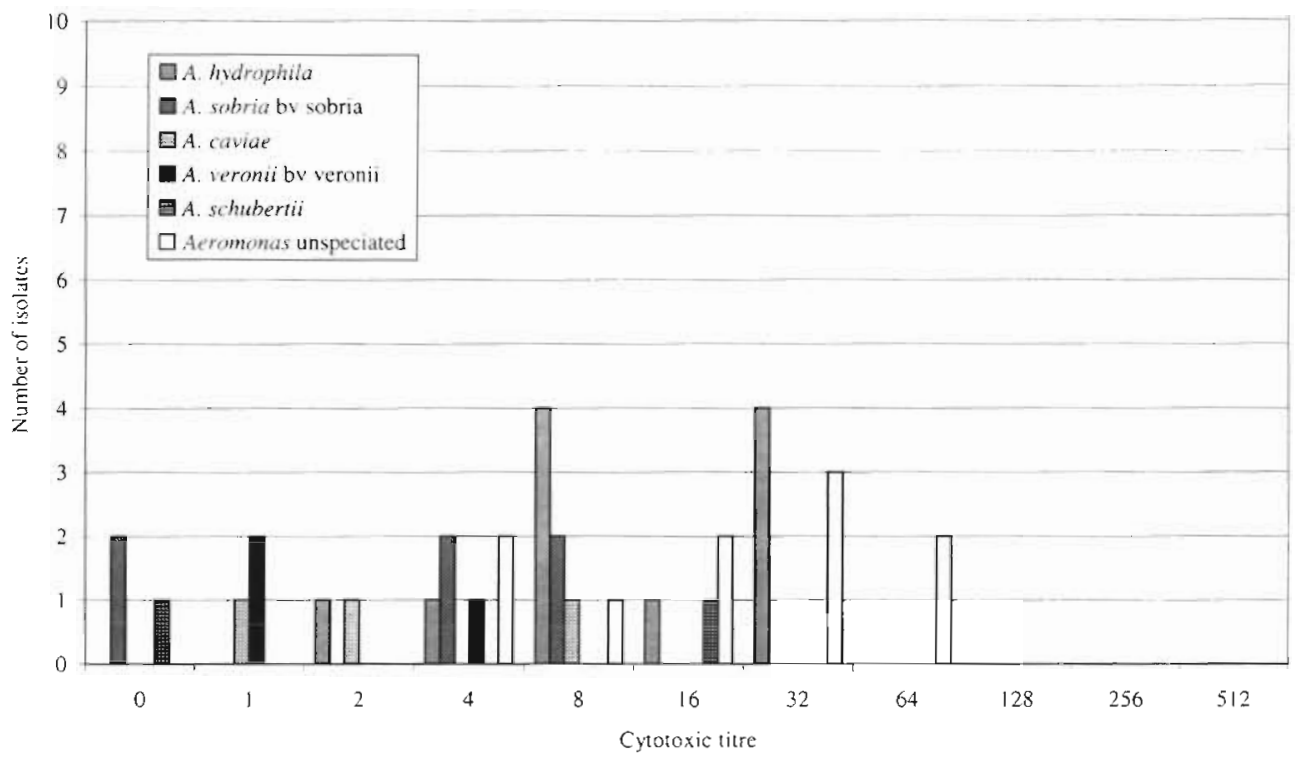

Fig. 5. Cytotoxic activity against $\mathrm{S} S \mathrm{~N}-1$ cells

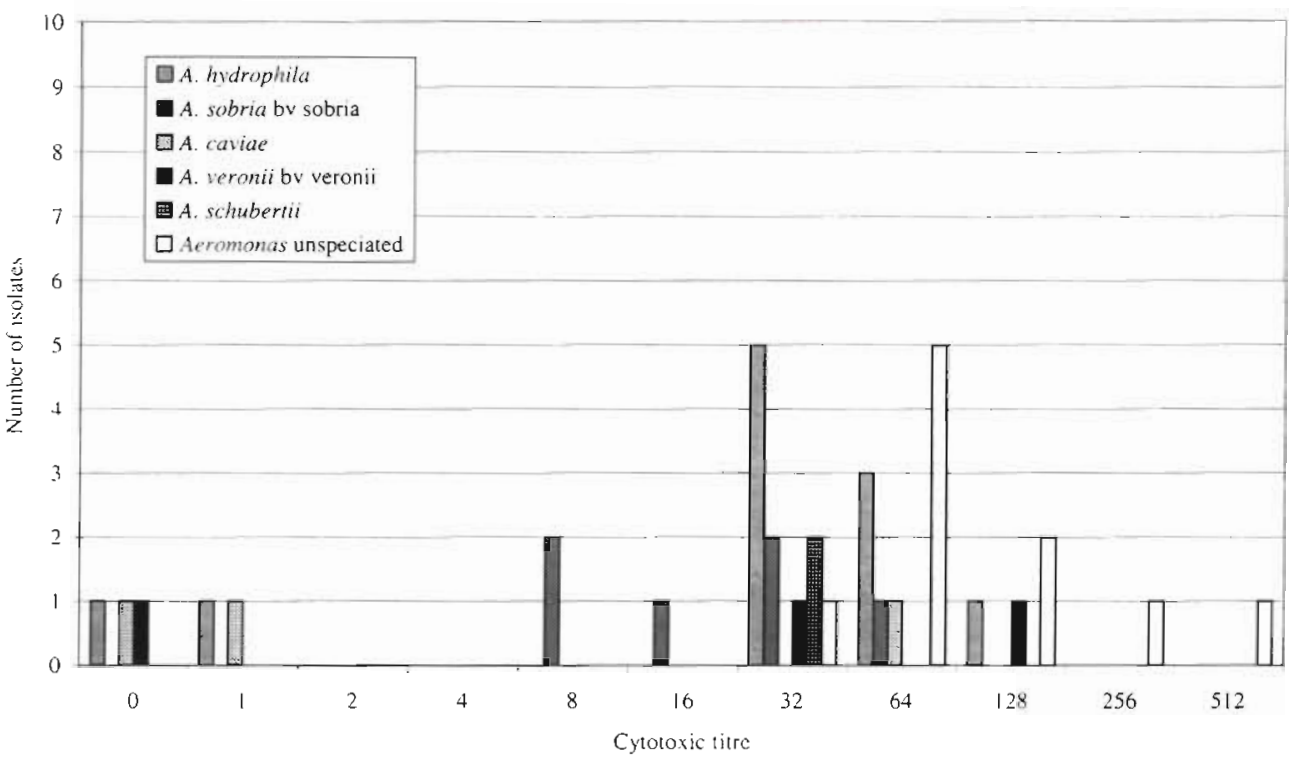

Fig. 6. Cytotoxic activity against HCT cells

monicida. In contrast, the aerolysin homologue AHH4 (cloned from $A$. hydrophila) hybridised with only $2 \mathrm{~A}$. hydrophila isolates from Thailand and wilh the lype strain of A. salmonicida. The ASA1 probe (cloned from A. sobria) hybridised with 4 out of $5 A$. veronii biovar sobria isolates from Thailand, with 1 out of 4 A. hydrophila from Thailand, with the single $A$. schubertii from Thailand, and with the type strains of $A$. sobria, $A$. veronii biovar sobria, $A$. veronii biovar veronii and $A$. schubertii. The ASH1 gene (cloned from A. salmonicida) hybridised with all 10 of the Au isolates but did not react with any of the other Thai aeromonads or type strains examined.

\section{DISCUSSION}

This study showed that haemolysin activitics against frog erythrocytes were significantly different amongst the collection of aeromonads. The isolates with high haemolytic activity ( $\mathrm{Au}$ ) were all found internally in septicaemic adult frogs, indicating that haemolysin production may be correlated to origin and potential virulence of Aeromonas isolates. A similar finding was obtained by Janda et al. (1994), who studied 20 isolates of Aeromonas from human blood and found that elevated levels of protease and haemolysin activity could be correlated with higher virulence. 
Several authors have reported a relationship between high elastase activity and virulence of bacterial strains (Hsu et al. 1981, Santos et al. 1988, Esteve et al. 1995). In the present study all but one of the Au isolates demonstrated elastinolytic activity, as did 3 of the 5 Aeromonas hydrophila isolates examined. None of the other motile aeromonads displayed any elastinolytic activity. There was a significant difference between the elastinolytic capabilities of the Au group and the other Aeromonas species but not between $\mathrm{Au}$ and $\mathrm{A}$. hydrophila. It is probable that possession of elastase enhances bacterial pathogenesis through degradation of critical host proteins but that elastinolytic abilities alone do not confer virulence on an isolate.

The cytotoxic activity of the Aeromonas ECP against the RTG-2 cells paralleled the division of their haemolytic activities into 3 groups of high, moderate and low. This cell line proved extremely sensitive to Au cytotoxin but less so to the toxins produced by other species. In contrast, the mammalian cell line (Vero) showed little sensitivity to the cytotoxins produced by

Table 2. Number of Aeromonas isolates reacting with haemolysin gene probes

\begin{tabular}{|c|c|c|c|c|c|c|}
\hline Species & Source & $\mathrm{n}$ & AHH1 & $\mathrm{AHH} 4^{\mathrm{b}}$ & $A S A 1^{\circ}$ & $\mathrm{ASH} 1^{\mathrm{d}}$ \\
\hline $\mathrm{Au}$ & Internal frog & 10 & 10 & 0 & 0 & 10 \\
\hline A. hydrophila & $\begin{array}{l}\text { External frog } \\
\text { Environment } \\
\text { Type strain }\end{array}$ & $\begin{array}{l}3 \\
1 \\
1\end{array}$ & $\begin{array}{l}2 \\
1 \\
1\end{array}$ & $\begin{array}{l}2 \\
0 \\
0\end{array}$ & $\begin{array}{l}1 \\
0 \\
0\end{array}$ & $\begin{array}{l}0 \\
0 \\
0\end{array}$ \\
\hline $\begin{array}{l}\text { A. veronii } \\
\text { bv sobria }\end{array}$ & $\begin{array}{l}\text { External frog } \\
\text { Environment } \\
\text { Type strain }\end{array}$ & $\begin{array}{l}4 \\
1 \\
1\end{array}$ & $\begin{array}{l}0 \\
0 \\
0\end{array}$ & $\begin{array}{l}0 \\
0 \\
0\end{array}$ & $\begin{array}{l}4 \\
0 \\
1\end{array}$ & $\begin{array}{l}0 \\
0 \\
0\end{array}$ \\
\hline A. schubertii & $\begin{array}{l}\text { External frog } \\
\text { Type strain }\end{array}$ & $\begin{array}{l}1 \\
1\end{array}$ & $\begin{array}{l}0 \\
0\end{array}$ & $\begin{array}{l}0 \\
0\end{array}$ & $\begin{array}{l}1 \\
1\end{array}$ & $\begin{array}{l}0 \\
0\end{array}$ \\
\hline $\begin{array}{l}\text { A. veronii } \\
\text { bv veronii }\end{array}$ & $\begin{array}{l}\text { External frog } \\
\text { Type strain }\end{array}$ & $\begin{array}{l}2 \\
1\end{array}$ & $\begin{array}{l}0 \\
0\end{array}$ & $\begin{array}{l}0 \\
0\end{array}$ & $\begin{array}{l}0 \\
1\end{array}$ & $\begin{array}{l}0 \\
0\end{array}$ \\
\hline A. caviae & $\begin{array}{l}\text { External frog } \\
\text { Type strain }\end{array}$ & $\begin{array}{l}2 \\
1\end{array}$ & $\begin{array}{l}0 \\
0\end{array}$ & $\begin{array}{l}0 \\
0\end{array}$ & $\begin{array}{l}0 \\
0\end{array}$ & $\begin{array}{l}0 \\
0\end{array}$ \\
\hline A. salmonicida & Type strain & 1 & 1 & 1 & 0 & 0 \\
\hline A. sobria & Type strain & 1 & 0 & 0 & 1 & 0 \\
\hline A. media & Type strain & 1 & 0 & 0 & 0 & 0 \\
\hline A. eucrenophila & Type strain & 1 & 0 & 0 & 0 & 0 \\
\hline A. jandaei & Type strain & 1 & 0 & 0 & 0 & 0 \\
\hline A. trota & Type strain & 1 & 0 & 0 & 0 & 0 \\
\hline A. allosaccharophila & Type strain & 1 & 0 & 0 & 0 & 0 \\
\hline A. encheleia & Type strain & 1 & 0 & 0 & 0 & 0 \\
\hline \multicolumn{7}{|c|}{$\begin{array}{l}\text { aAHH1 gene cloned from } A \text {. hydrophila, low sequence homology }(42 \%) \\
\text { with aerolysin gene }\end{array}$} \\
\hline \multicolumn{7}{|c|}{$\begin{array}{l}\text { 'AHH4 gene cloned from A. hydrophila, high sequence homology (93\%) } \\
\text { with aerolysin gene }\end{array}$} \\
\hline \multicolumn{7}{|c|}{$\begin{array}{l}\text { 'ASA1 gene cloned from A. sobria, significant sequence homology }(66 \%) \\
\text { with aerolysin gene }\end{array}$} \\
\hline \multicolumn{7}{|c|}{$\begin{array}{l}\text { 'ASH1 gene cloned from } A \text {. salmonicida, no significant sequence homolo- } \\
\text { gies with bacterial haemolytic proteins in GenBank-EMBL DNA database }\end{array}$} \\
\hline
\end{tabular}

the Au isolates but were more sensitive to those toxins produced by the A. hydrophila group.

In the past Vero cells have been recommended as the cell line most appropriate for screening Aeromonas cytotoxins (Kuijper et al. 1989. Noterdaeme et al. 1991). Many studies have used Vero cells alone to screen for cytotoxins (Vadivelu et al. 1991, 1995, Majeed \& MacRae 1994). While this assay may be appropriate for studies on human isolates, caution should be exercised when interpreting results for isolates of aquatic origin.

These findings supplement and support those of 2 earlier studies. Bernheimer et al. (1975) investigated the sensitivity to aerolysin of erythrocytes from 11 different animal species (all mammalian). Their results showed that RBC from different mammals differed greatly in sensitivity to lysis by purified aerolysin. Those from rat were 300 times more sensitive than those from sheep, whereas RBC from other species exhibited intermediate degrees of sensitivity or resistance. Nzeako et al. (1991) examined haemolysin production of Aeromonas hydrophila isolates using different cultural methods and erythrocytes from 6 different animal species. The authors concluded that A. hydrophila produced multiple haemolysins which had differing specificities for particular types of erythrocytes.

These papers illustrate the importance of selecting reagents appropriate to the strain and origin of isolates under investigation. Paniagua et al. (1990) examined virulence factors of 97 motile Aeromonas spp. isolated from a river but found no correlation between caesinase, haemolytic and cytolytic activities and virulence for rainbow trout. The findings, however, may have been different had the authors used RBC from a source other than sheep.

Vadivelu et al. (1991) in a study of human clinical isolates found that some isolates produced either cytotoxin or haemolysin alone and concluded therefore that the haemolysin and the cytotoxin may be 2 different proteins. In their study only Vero cells and rabbit erythrocytes were used to determine toxic activity and this may have influenced the results. It will not be possible to determine whether the cytotoxin and haemolysin are the same factor until each toxin has been purified and assayed against a range of RBC origins and cell culture types. 
The results presented in this study demonstrated that the haemolytic abilities of the Au isolates against frog erythrocytes were significantly higher than those of the Aeromonas hydrophila isolates and other Aeromonas species. The colony hybridisation studies revealed that $\mathrm{Au}$ isolates possessed haemolysin genes which differed from those of the other Aeromonas isolates. In particular, the gene ASH1 was present in $\mathrm{Au}$ and in none of the other Thai aeromonads or type strains tested. Previous work with haemolysin gene probes had indicated that almost all motile aeromonads possess either the sobria gene ASA1 (or one of its homologues) or the hydrophila gene AHH4 (Hirono et al. 1992, Hirono \& Aoki 1993). Au therefore is unusual among the motile aeromonads in possessing neither of these genes although both were present in other motile aeromonads from Thailand.

It is interesting that all 10 of the Au isolates possessed the ASH1 gene as this had previously only been found in a single Aeromonas salmonicida isolate. It was originally thought that this gene did not originate in aeromonads but was acquired from another genus during bacterial passage in the laboratory (Hirono \& Aoki 1993). The fact that all 10 of the Au isolates possessed this gene indicates that it does in fact belong to the genus Aeromonas and may explain the higher haemolytic activity against frog $\mathrm{RBC}$ of the $\mathrm{Au}$ isolates in comparison to the other motile aeromonads from Thailand. As indicated by the work of Bernheimer et al. (1975) and Nzeako et al. (1991), it is probable that the products of differing haemolysin genes have a range of activities against cells from various sources. The aerolysin gene product may be active against cells of mammalian origin while the ASH1 product is active against cells from aquatic animals.

Chakraborty et al. (1987) presented genetic evidence that the aerolysin structural gene aer $A$ is found in all members of the genus. Howard et al. (1996) suggest that this gene is not found in other bacteria and that it may be considered a distinguishing feature of the genus Aeromonas. DNA hybridisation studies, however, by Hirono et al. (1992) indicated that only 4 of $14(28.6 \%)$ clinically isolated strains of motile Aeromonas spp. contained nucleotide sequences homologous to the $\mathcal{A}$. hydrophila aeroiysin gene, therefore raising doubts about the use of this gene to distinguish the genus. The present study confirms this finding, only 3 of the 37 isolates tested contained the AHH4 homologue of aerolysin and only a further 10 isolates contained sequences homologous to the closely related A. sobria aerolysin ASA1. The Au isolates although highly haemolytic for frog erythrocytes contained genes AHH1 and ASH1. The AHH1 gene has low homology with aerolysin while ASH1 does not have homologous sequences with any bacterial haemolytic proteins present in the DNA data banks. The use of aerolysin as a marker for the genus Aeromonas is therefore questionable.

In conclusion, the finding that Au was highly haemolytic for frog erythrocytes and cytotoxic for rainbow trout cells indicates that the isolates are more likely to be virulent for these species. The possession of the ASH1 gene may be related to these properties, it was only present in Au isolated from the internal organs of septicaemic frogs, and was first cloned from a strain of Aeromonas salmonicida isolated by S. F. Snieszko from a diseased brook trout (American Type Culture Collection 1992). If the gene does encode for a toxin active against both trout and frog cells, then further studies are indicated to isolate the pure gene product by genetic manipulation and identify its role in the disease process.

Acknowledgements. This work was supported by the British Government through grants awarded by the Biotechnology and Biological Research Council, and the Overseas Development Administration (now Department for International Development), and by the Japanese Government through a fellowship awarded by the Japan Society for the Promotion of Science. The authors wish to thank Ms Nahoko Tange for her help with the genotypic analyses and Dr Jimmy Turnbull for his advice on statistical analyses.

\section{LITERATURE CITED}

American Type Culture Collection (1992) Catalogue of bacteria and bacteriophages, 18th edn. ATCC, MD, p 18

Aoki T, Hirono I (1991) Cloning and characterisation of the haemolysin determinants from Aeromonas hydrophila. J Fish Dis 14:303-312

Asao T, Konoshita S, Kozaki S, Uemura T, Sakaguchi G (1984) Purification and some properties of Aeromonas hydrophila haemolysin. Infect Immun 59:122-127

Bernheimer AW, Avigad LS, Avigad G (1975) Interactions between aerolysin, erythrocytes, and erythrocyte membranes. Infect Immun 11:1312-1319

Cahill MM (1990) Virulence factors in motile Aeromonas species. J Appl Bacteriol 69:1-16

Carnahan AM, Altwegg M (1996) Taxonomy. In: Austin B, Altwegg M, Gosling PJ, Joseph S (eds) The genus Aeromonas. John Wiley \& Sons Ltd, Chichester, p 1-38

Carnahan AM, Behram S, Joseph SW (1991) Aerokey II: a flexible key for identifying clinical Aeromonas species. $\mathrm{J}$ Clin Microbiol 29:2843-2849

Chakraborty $T$, Huhle B, Hof $\mathrm{H}$, Bergbauer $\mathrm{H}$, Goebel W (1987) Marker exchange mutagenesis of the aerolysin determinant in Aeromonas hydrophila demonstrates the role of aerolysin in $A$. hydrophila-associated systemic infections. Infect Immun 55:2274-2280

Esteve C, Amaro C, Garay E, Santos Y, Toranzo AE (1995) Pathogenicity of live bacteria and extracellular products of motile Aeromonas isolated from eels. J Appl Bacteriol 78: 555-562

Hirono I, Aoki T (1992) Cloning and expression of a haemolysin gene from Aeromonas salmonicida ATCC 14174. In: Shariff $M$, Subasinghe RP, Arthur JR (eds) Diseases in Asian aquaculture. I. Fish Health Section, Asian Fisheries Society, Manila, p 305-311 
Hirono I Aoki T (1993) Cloning and characterisation of three haemolysin genes from Aeromonas salmonicida. Microb Pathog 15:269-282

Hirono I, Aoki T, Asao T, Kozaki S (1992) Nucelotide sequences and characterisation of haemolysin genes from Aeromonas hydrophila and Aeromonas sobria. Microb Pathog 13:433-446

Howard SP, Garland WJ, Green MJ, Buckley JT (1987) Nucleotide sequence of the gene for the hole-forming toxin aerolysin of Aeromonas hydrophila. J Bacteriol 169: $2869-2871$

Howard SP, MacIntyre S, Buckley JT (1996) Toxins. In: Austin B, Altwegg M, Gosling PJ, Joseph S (eds) The genus Aeromonas. John Wiley \& Sons Ltd, Chichester, p 267-286

Hsu TC, Waltman WD, Shotts EB (1981) Correlation of extracellular enzymatic activity and biochemical characteristics with regard to virulence of Aeromonas hydrophila. Dev Biol Standards 49:101-111

Janda JM (1991) Recent advances in the study of the taxonomy, pathogenicity, and infectious syndromes associated with the genus Aeromonas. Clin Microbiol Rev 4:397-410

Janda JM, Duffey PS (1988) Mesophilic aeromonads in human disease: current taxonomy, laboratory identification, and infectious disease spectrum. Rev Infect Dis 10: 980-997

Janda JM, Guthertz LS, Kokka RP, Shimada T (1994) Aeromonas species in septicaemia: laboratory characteristics and clinical observations. Clin Infect Dis 19:77-83

Joseph SW, Carnahan A (1994) The isolation, identification, and systematics of the motile Aeromonas species. Annu Rev Fish Dis 4:315-343

Kirov SM, Hudson JA, Hayward LJ, Mott SJ (1994) Distribution of Aeromonas hydrophila hybridisation groups and their virulence properties in Australasian clinical and environmental strains. Lett Appl Microbiol 18:71-73

Kuijper EJ, Steigerwalt AG, Schoenmakers BSCIM, Peeters MF, Zanen HC, Brenner DJ (1989) Phenotypic characterisation and DNA relatedness in human faecal isolates of Aeromonas spp. J Clin Microbiol 27:132-138
Majeed KN, MacRae IC (1994) Cytotoxic and haemagglutinating activities of motile Aeromonas species. J Med Microbiol 40:188-193

Noterdaeme L, Bigawa S, Willems KA, Ollevier F (1991) Biochemical and physiological characteristics and plasmid profiles of Aeromonas hydrophila strains, isolated from freshwater fish and from fresh water. J Fish Dis 14 $313-321$

Nzeako BC, Hastings TS, Ellis AE (1991) Cultural conditions for Aeromonas hydrophila affect the production of haemolysins with differing host specificities. Antonie Leeuwenhoek 60:67-72

Paniagua C, Rivero O, Anguita J, Naharro G (1990) Pathogenicity factors and virulence for rainbow trout (Salmo gairdneri) of motile Aeromonas spp. isolated from a river. $\mathrm{J}$ Clin Microbiol 28:350-355

Pearson MD, Colquhoun D, Somsiri T, Inglis V (1997) Biochemical characterisation and RAPD analysis of an Aeromonas species isolated from septicaemic Rana rugulosa (Weigmann) cultured in Thailand. In: Flegel TW, MacRae IH (eds) Diseases in Asian aquaculture. ILI. Fish Health Section, Asian Fisheries Society, Manila, p 9-14

Pin C, Marin ML, Selgas ML, Garcia ML, Tormo J, Casas C (1994) Virulence factors in clinical and food isolates of Aeromonas species. Folia Microbiol 39:331-336

Santos Y, Toranzo AE, Barja JL, Nieto TP, Villa TGV (1988) Virulence properties and enterotoxin production of Aeromonas strains isolated from fish. Infect Immun 56: 3285-3293

Vadivelu J, Puthucheary SD, Navaratnam P (1991) Exotoxin profiles of clinical isolates of Aeromonas hydrophila. J Med Microbiol 35:363-367

Vadivelu J, Puthucheary SD, Phipps M, Chee YW (1995) Possible virulence factors involved in bacteraemia caused by Aeromonas hydrophila. J Med Microbiol 42:171-174

Wilcox MH, Cook A, Geary I, Eley A (1994) Toxin production adherence and protein expression by clinical Aeromonas spp. isolates in broth and human pooled ileostomy fluid Epidemiol Infect 113:235-245

Submitted: October 6, 1999; Accepted: December 17, 1999 Proofs received from author(s): April 12, 2000
Editorial responsibility: David Bruno,

Aberdeen, Scotland, UK 